\title{
Anti-Hepatotoxic and Antioxidant Activity of Limnanthemum indicum Against Carbon Tetrachloride Induced Liver Toxicity in Rats
}

\author{
Jyothi Yachamaneni ${ }^{1 *}$, Sangeetha Dhanraj ${ }^{2}$ \\ ${ }^{1}$ Department of Pharmacology, Krupanidhi college of Pharmacy, Bangalore-35, Karnataka, INDIA. \\ ${ }^{2}$ School of Advanced Sciences, Vellore Institute of Technology, Vellore, Tamil Nadu, INDIA.
}

\begin{abstract}
Objective: Whole plant of Limnanthemum indicum (Menyanthaceae) is traditionally used for liver disorders. Limnanthemum indicum was investigated for its Anti-hepatotoxic and Antioxidant activity. Materials and Methods: Alcoholic extract of whole plant of Limnanthemum indicum $(100,200,400 \mathrm{mg} / \mathrm{kg}$, p.o.) was evaluated for its Anti-hepatotoxic and Antioxidant activity in Carbon tetrachloride $\left(\mathrm{CCl}_{4}\right)$-induced liver toxicity in Rats. The Anti-hepatotoxic activity was assessed from biochemical and histopathological studies. Results:The administration of $\mathrm{CCl}_{4}$ in rats induced hepatotoxicity which was evidenced by increased levels of Aspartate aminotransferase Alanine aminotransferase, Alkaline phosphatase and total bilirubin and oxidative stress. Pretreatment with Limnanthemum indicum extract significantly protected the liver in Carbon tetrachloride administered rats. Limnanthemum indicum extract significantly elevated antioxidant enzymes like superoxide dismutase, catalase, glutathione, Glutathione peroxidase, Gamma glutamyl Transferase and Glutathione- S-Transferase and decreased lipid peroxidation levels in liver. Histological studies showed that Limnanthemum indicum at $400 \mathrm{mg} / \mathrm{kg}$ reduced the hepatocellular damage in $\mathrm{CCl}_{4}$ treated Rats. Conclusion: Thus the alcoholic extract of Limnanthemum indicum shows good antihepatoxic and antioxidant activity.
\end{abstract}

Key words: Carbon tetrachloride, Hepatoprotective, Limnanthemum indicum, Antioxidant, Alcohoic extract, histopathology.

\section{INTRODUCTION}

Free radicals are generated in cells by environmental factors such as $\mathrm{x}$-rays, pollutants, ultraviolet radiation, as well as by normal metabolism. These free radicals induce Oxidative stress and can lead to injury of cellular membrane and variations in the metabolic processes. Reactive oxygen species (ROS) play an important role in the developme nt of various degenerative human diseases and have been implicated in liver disorders, atherosclerosis, lung and kidney damage, aging and diabetyes mellitus. In liver disorders the ability of the natural antioxidant system is impaired. Carbon tetrachloride $\left(\mathrm{CCl}_{4}\right)$ is a classic hepatotoxin widely used in various experimental models. $\mathrm{CCl}_{4}$ induces liver injuries by mediating through the formation of its reactive intermediates such as trichloromethyl radical $\left(\mathrm{CCl}_{3}{ }^{\bullet}\right)$ and its derivative trichloromethyl peroxy radical $\left(\mathrm{CCl}_{3} \mathrm{OO} \bullet\right)$, produced by cytochrome $\mathrm{P}_{450}$ of liver microsomes. These free radicals generated react with membrane lipids leading to their peroxidation. ${ }^{1}$ Membrane disintegration of hepaocytes with subsequent elevation of marker enzymes Aspartate transaminase (AST), Alanine transaminase (ALT), Alkaline phosphatase (ALP), Lactate dehydrogenase (LDH) and g-glutamyl transferase (g-GT) indicative of hepatotoxicity, centrilobular necrosis and steatosis are some of the histological damages caused by of $\mathrm{CCl}_{4^{-}}$induced lipid peroxidation. The intracellular concentration of ROS
Submission Date: 30-08-2016; Revision Date: 17-11-2016; Accepted Date: 23-11-2016

DOI: $10.5530 / \mathrm{ijper.51.2.38}$ Correspondence: Jyothi.Y,

Assoc.Professor,Department of Pharmacology Krupanidhi college of Pharmacy, Bangalore Phone Number-7259519535 E-mail: jokiran05@gmail.com

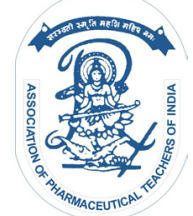

www.ijper.org 
is a result of both their production and removal by various endogenous antioxidants including both enzymatic and nonenzymatic components. ${ }^{2,3}$ Although a wide range of drugs are currently employed in the management of hepatic disorders. However, alternative approach in recent days is the recent days are the research of medicament from traditional medicinal systems. Inhibition of free radicals is very important in terms of liver pathology. Natural products from the plant kingdom are being investigated as a source of antioxidants as these may have great relevance in the prevention of diseases associated with oxidative stress. ${ }^{2,4}$ Limnanthemum indicum is an aquatic floating herb belonging to the Menyanthaceae family commonly called as water snow flake. ${ }^{5}$ It is traditionally used as bitter, febrifuge and antiscorbutic. ${ }^{6}$ It is used as a substitute for Swertia chirata for the treatment of fever and jaundice. ${ }^{7}$ It has been reported that Limnanthemum indicum contains different sub types of flavonoid. ${ }^{8}$ It is used as a substitute of Ayurvedic drug Tagara in the treatment of various diseases like epilepsy ${ }^{9}$, anemia, jaundice, tuberculosis. ${ }^{10}$ It is reported that the whole plant of Limnanthemum indicum is traditionally used as hepatoprotective. ${ }^{11}$ Limnanthemum indicum has been also reported to show a good anti-proliferative activity. ${ }^{12}$

To best of our knowledge there was lack of scientific reports available in support of its traditional use as hepatoprotective. Therefore, present study was designed to demonstrate the effect of Alcoholic extract of whole plant of Limnanthemum indicum (LIAE) against $\mathrm{CCl}_{4}$ induced hepatic damage in experimental animals.

\section{MATERIALS AND METHODS}

\section{Chemicals}

All the chemicals used were of analytical grade and procured from Sigma chemicals Co., USA and Qualigens fine chemicals, Mumbai, India.

\section{Collection and Authentication}

For the study whole plants of Limnanthemum indicum were collected from the local market, Tirunelveli town, Tamilnadu state. It is identified and authenticated by Prof. V.Chelladurai, Botanist, Central council for research in Ayurveda and Siddha, Govt of India, Tirunelveli, Tamilnadu and a voucher specimen was also deposited for future reference.

\section{Preparation of Plant extract}

Approximately three kilograms of the whole plant of Limnanthemum indicum was collected and washed in running tap water. Then they were cut into small pieces and dried under shade for about four weeks and finely ground to coarse power in a blender. Initially 150 gms of material was packed into the thimble and 2.5 liters of solvent used for extraction was poured into flask (Round Bottom flask). The soxhlet extraction was performed for 18-24 hours until the collected liquid in siphon tube appears clear. Later the extracted solvent was evaporated under reduced pressure to get dried powder of extract.

\section{Animals}

Male Wistar rats weighing (150-200 g) were procured fro Radiant Research Pvt Limited, Bangalore. These animals were housed in a cross ventilated room and $22 \pm 2^{\circ} \mathrm{C}$ with light and dark cycles of $12 \mathrm{hr}$ for 1 week before and during the experiments. All studies and performed in accordance with the guideline for the care and use of laboratory animals, as adopted and promulgated by the Institutional animal Ethical Committee, CPCSEA, India (Reg. No.RRPL/06/CPCSEA).

\section{Acute Oral Toxicity Studies}

The acute toxicity test was performed according to the Organization of Economic Co-operation and Development (OECD) guideline 423 for testing of chemicals. ${ }^{13}$ Female rats were used for the acute toxicity study. LIAE extracts were given up to $2000 \mathrm{mg} / \mathrm{kg}$ individually, by oral route using oral feeding needle and the $\mathrm{LD}_{50}$ values were calculated (OECD-423).

\section{Carbon tetrachloride $\left(\mathrm{CCl}_{4}\right)$-induced hepatotoxicity}

In this study 36 Male Wistar rats are used. Their average weight was 150-200 gms and were divided into 6 groups containing 6 animals in each group. Group I (Normal Control) received $0.5 \%$ Sodium CMC for 7 days (p.o). Group II (Toxic Control) received Carbon tetra chloride $\left(\mathrm{CCl}_{4}+\right.$ Olive oil in 1:1 ratio; $2 \mathrm{ml} / \mathrm{kg}$ of body wt; i.p) on day 1 and day 7. Group III receive Standard drug (Liv-52, $40 \mathrm{mg} / \mathrm{kg}, \mathrm{p} . \mathrm{o})$ once in a day for 7 days, along with the i.p dose of $\mathrm{CCl}_{4}$ on day 1 and day 7. Group IV, V, VI received Alcoholic extract of whole plant of Limnanthemum indicum (LIAE) $(100 \mathrm{mg} / \mathrm{kg}, 200 \mathrm{mg} / \mathrm{kg}$ and $400 \mathrm{mg} / \mathrm{kg}$ b.w) once in a day for 7 days, along with the i.p dose of $\mathrm{CCl}_{4}$ on day 1 and day 7 . On the $8^{\text {th }}$ day, the blood was collected from each animal and serum was separated by centrifugation. Further serum was used for various biochemical assays. The animals were sacrificed under anesthesia to isolate the liver for histopathological studies.

\section{Assessment of Anti-hepatotoxic activity}

The collected blood was allowed to clot and serum was separated at $2500 \mathrm{rpm}$ for $15 \mathrm{~min}$ and used for the esti- 
mation of biochemical parameters like serum enzymes: Aspartate aminotransferase (AST, U/L), ${ }^{14}$ Alanine aminotransferase (ALT, U/L), ${ }^{15}$ Alkaline phosphatase (ALP, U/L) ${ }^{16}$ Total bilirubin $(\mathrm{mg} / \mathrm{dL})^{17}$ and Total protein $(\mathrm{TP}, \mathrm{g} / \mathrm{dl}) .{ }^{18}$

\section{Assessment of Antioxidant parameters}

The dissected out liver samples were washed immediately with ice cold saline to remove as much blood as possible. Liver homogenized (5\%) in ice cold $0.9 \%$ $\mathrm{NaCl}$ with a Potter-Elvenhjem glass homogenizer. The homogenate was centrifuged at 800 for $10 \mathrm{~min}$ and the supernatant was again centrifuged at 12,000 for $15 \mathrm{~min}$ and the obtained mitochondrial fraction was used for the estimation of Super oxide dismutase (SOD), Catalase (CAT), Lipid peroxidase(LPO), Reduced Glutathione (GSH), Glutathione peroxidase (GPx), Gamma glutamyl Transferase (GGT) and Glutathione -S-Transferase (GST). ${ }^{19-25}$

\section{Histopathological studies}

For histopathological studies, rats from all the experimental groups were perfused with 10 per cent neutral formalin solution. Liver was removed immediately from the rat; paraffin sections were made and stained by hematoxylin-eosin (H\&E). After staining, the sections were observed under light microscope.

\section{Statistical analysis}

Statistical differences were assessed by analysis of variance (ANOVA) followed by Tukey test.

$P<0.05$ was considered statistically significant. All the results were expressed as mean \pm SEM.

\section{RESULTS}

\section{Acute Oral toxicity Studies}

The $\mathrm{LD}_{50}$ value for LIAE was found to be $2000 \mathrm{mg} / \mathrm{kg} /$ oral body weight individually. There was no alteration in gross behavior effects visually when compared with control group animals.

\section{Effect of LIAE on serum AST, ALT, ALP, TB and TP level against $\mathrm{CCl}_{4}$ induced liver toxicity}

The in vivo Anti-hepatotoxic activity of Alcoholic extract of Limnathemum indicum (LIAE) was studied in $\mathrm{CCl}_{4}$ intoxicated rats at three dose levels $(100 \mathrm{mg} / \mathrm{kg}$, $200 \mathrm{mg} / \mathrm{kg}$ and $400 \mathrm{mg} / \mathrm{kg}$ b.w, p.o) and standard (Liv-52, $40 \mathrm{mg} / \mathrm{kg}$, p.o).

Intoxication of rats with $\mathrm{CCl}_{4}(2 \mathrm{ml} / \mathrm{kg})$ significantly altered the biochemical parameters when compared with the normal control rats $(\mathrm{P}<0.001)$ compared to normal control (Group I). A significant increase in the level of ALT, AST, ALP, total bilirubin (TB) and total protein (TP) were observed in toxicant induced group. Treatment with Alcoholic extract of Limnathemum indicum (LIAE) at the dose level of $400 \mathrm{mg} / \mathrm{kg}$ b.w significantly reduced the levels of ALT, AST, ALP, total bilirubin (TB) and total protein (TP) towards the normal values.

\section{Histopathology}

Normal histological structures of hepatic lobules were observed in normal liver (Figure 1). Section studied shows normal hepatocytes arranged in lobular pattern around the central veins. These lobules are surrounded by normal portal triads containing portal venule, hepatic arteriole and bile ductule. The hepatic sinusoids are normal with normal connective tissue stroma. No Necrosis, fatty change or malignant cells seen.

Rats treated with carbon tetra chloride Section studied shows hepatocytes arranged in lobular pattern around the central veins. These lobules show necrosis predominantly around the central vein (centrilobular necrosis). These areas of necrosis consist of degenerating neutrophils, RBCs and necrotic debris. The hepatic sinusoids and portal triads are normal with normal connective tissue stroma. No fatty change or malignant cells seen (Figure 2). Liv.52 (Figure 3) studied section studied shows hepatocytes arranged in lobular pattern around the central veins with mild loss of architechture. These lobules show necrosis predominantly around the central vein (centrilobular necrosis). These areas of necrosis consists of degenerating neutrophils, RBCs and necrotic debris. Many areas of fatty vascular degeneration are seen scattered all over. The hepatic sinusoids show congestion, filled with RBCs. Portal triads are normal with normal connective tissue stroma.

Alcoholic extract of Limnathemum indicum $(100 \mathrm{mg} / \mathrm{kg}$ \& $200 \mathrm{mg} / \mathrm{kg}$, b.w, p.o) (Figure 4 \& 5) sections studied shows hepatocytes arranged in lobular pattern around the central veins with normal architecture. Very minimal areas of necrosis noted. Many areas of fatty vascular degeneration are seen scattered all over. The hepatic sinusoids and portal triads are normal with normal connective tissue stroma.

Alcoholic extract of Limnathemum indicum $(400 \mathrm{mg} / \mathrm{kg}$, b.w, p.o) (Figure 6) Section studied shows hepatocytes arranged in lobular pattern around the central veins with moderate loss of architechture. These lobules show necrosis predominantly around the central vein (centrilobular necrosis) with confluent necrosis all over the tissue. These areas of necrosis consist of degenerating neutrophils, rbcs and necrotic debris. Few areas of fatty vascular degeneration are seen scattered all over. The 
hepatic sinusoids show congestion, filled with RBCs. Portal triads are normal with normal connective tissue stroma.

\section{Assessment of Antioxidant activity}

In liver homogenate, there was significant decrease in SOD, CAT, GSH, GST, GGT and GPx levels and increase in LPO levels was observed in animals treated with $\mathrm{CCl}_{4} 400 \mathrm{mg} / \mathrm{kg}$ (Group II) as compared to the normal control group (Group I). Pretreatment with Alcoholic extract of Limnathemum indicum (LIAE) at a dose of $400 \mathrm{mg} / \mathrm{kg}$ orally and Liv.52 (40 mg/kg) increase the levels of above parameters like SOD, CAT, GSH, GST, GGT and GPx levels and decrease levels of LPO significantly $(\mathrm{P}<0.01)$ whereas Alcoholic extracts of Limnathemum indicum (LIAE) at a dose of $200 \mathrm{mg} / \mathrm{kg}$ and $300 \mathrm{mg} / \mathrm{kg}$ not changed the above parameters significantly.

\section{DISCUSSION}

Any disease/disorder is associated with cell injury due to the generation of free radicals like superoxide anion $\left(\mathrm{O}_{2} \cdot\right)$, NO radical, $\mathrm{NOO} \cdot \mathrm{OH} \cdot$ and $\mathrm{H}_{2} \mathrm{O}_{2}$ radical. Free radicals generated damage the cell membrane and cellular constituents like DNA etc. resulting in various pathological conditions. ${ }^{32}$ Though the free radicals are generated even in normal physiological conditions and human beings possess the inbuilt natural antioxidant enzymes such as SOD, CAT, GPX, GST, and GGT to scavenge the generated free radicals. However, during prolonged stressful conditions the free radicals produced cannot be handled by our inbuilt mechanisms alone. Even the released free radicals react with the membrane polyunsaturated fatty acid and oxidise them to lipid peroxides. This lipid peroxidation damages membrane protein as well as the lipids. Thereby, the integrity of the membrane is lost. Hence, it is considered that the extent of lipid peroxidation is directly proportional to cell damage. In addition, the free radicals may also attack DNA and causes tissue damage. $\mathrm{CCl}_{4}$ administration in rats disrupts the membrane permeability of the plasma membrane causing leakage of the enzymes from the cell, which leads to elevation in levels of serum enzymes. It is apparent that the levels of SGPT, SGOT, ALP, total cholesterol, and total and direct bilirubin increased significantly in group treated with $\mathrm{CCl}_{4}$ comparing to normal control and it is an obvious indication of hepatic insult. Study of any herbal medicine becomes more significant when it ameliorates some diseases conditions. Any compound, natural or synthetic, with antioxidant properties may contribute towards the partial or total alleviation of this type of damage.
In the first part of the investigation, hepatoprotective effects of the ethanolic extract of Limnanthemum indicum (LIAE) was studied based on $\mathrm{CCl}_{4}$ induced liver hepatitis. The rats were pre-treated with LIAE at three dose levels (100 mg/kg, $200 \mathrm{mg} / \mathrm{kg}, 400 \mathrm{mg} / \mathrm{kg}$ b.w, p.o) for 7 days before challenging them with the $\mathrm{CCl}_{4}(2 \mathrm{ml} / \mathrm{kg}$ b.w). The severity of the damage caused to liver is reflected by increase in the level of serum enzymes. ${ }^{26}$ Further, the increase in the level of serum enzymes in blood is associated with excessive centrilobular necrosis, cellular degeneration and cellular infiltration of the liver and this is obvious from the hostopathological study. Administration of $\mathrm{CCl}_{4}$ to toxic control group (Group II) rats markedly increased serum AST, ALT, ALP, total bilirubin and decreased total protein levels. The level of serum enzymes are related to the function of the hepatic cell and increase in there level is attributing to their increased synthesis. ${ }^{27}$ The increase in the level of transaminases and alkaline phosphatase enzyme is a clear indication of cellular leakage and loss of functional integrity of the membrane resulting from liver damage. ${ }^{28,29}$ The rise in SGOT, SGPT, ALP, and bilirubin levels induced by $\mathrm{CCl}_{4}$ administration was significantly reduced by the plant of the present study and this decline was highly significant at higher dose of the extract i.e. $400 \mathrm{mg} / \mathrm{kg}$. This study also showed that the effect produced by administration of LIAE (400 mg/kg, b.w, p.o) was comparable with the hepatoprotection offered by the standard drug Liv.52. Hence hepatoprotectiove activity of the plant might be due its effect against cellular leakage and loss of functional integrity of the cell membrane in hepatocytes.

In the seocnd phase of the investigation, antioxidant activity of ethanolic extract of Limnanthemum indicum (LIAE) was studied. Elevated levels of LPO was observed in $\mathrm{CCl}_{4}$ treated rats indicated the excessive formation of free radicals and activation of lipid peroxidation system resulting in liver damage. The significant decline indicates its anti-lipid peroxidative effect in a dose dependent manner. It is possible that trichloromethyl radical or lipid peroxides generated by $\mathrm{CCl}_{4}$ treatment may be scavenged by the extract resulting in depression of lipid peroxidation in the liver. The antioxidant and free radical scavenging activity of LIAE(400 $\mathrm{mg} / \mathrm{kg}$, b.w, p.o) could be due to its constituent flavonoids and phenolic compounds. ${ }^{43}$ Glutathione is a major non-protein thiol in living organism and it is capable of preventing damage to important cellular components caused by reactive oxygen species such as free radicals, peroxides, lipid peroxides generated by toxins. ${ }^{30,31}$ Pretreatment with $\mathrm{CCl}_{4}$ significantly cause reduction in the GSH level and the levels are brought back to normal 


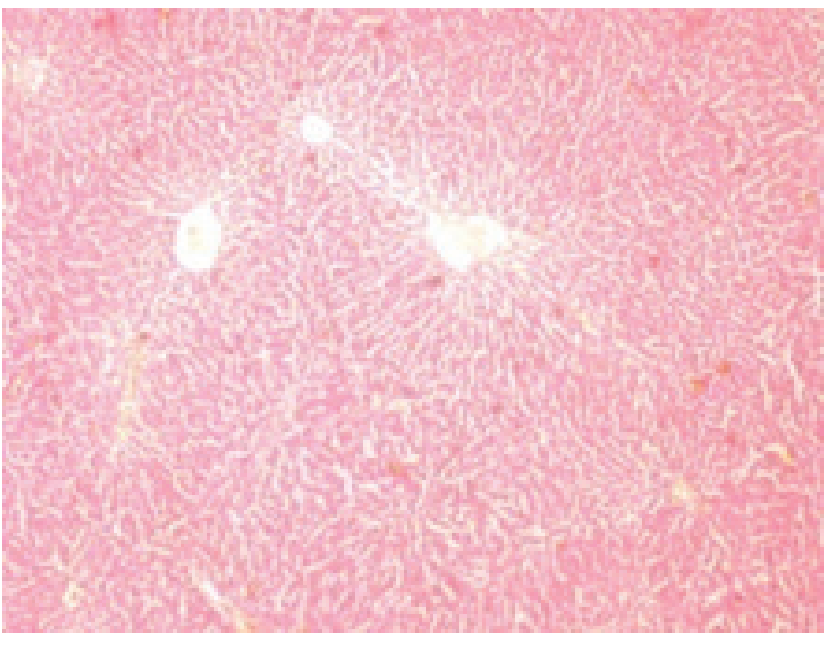

Figure 1: Normal Control

$H \& E-100 x$

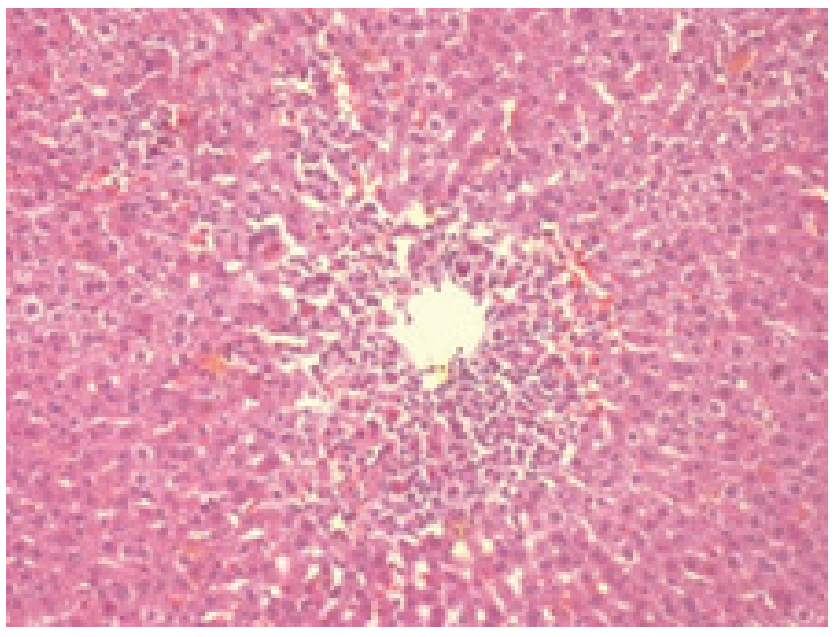

Figure 2: $\mathrm{CCl}_{4}$ Treated

$H \& E-100 x$

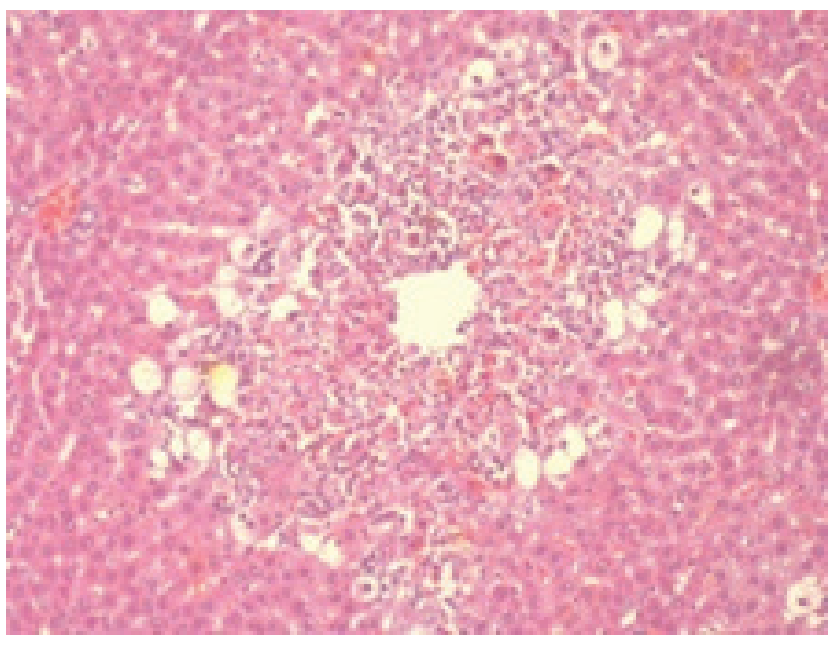

Figure 3: Liv $52(40 \mathrm{mg} / \mathrm{kg})$ $H \& E-100 x$

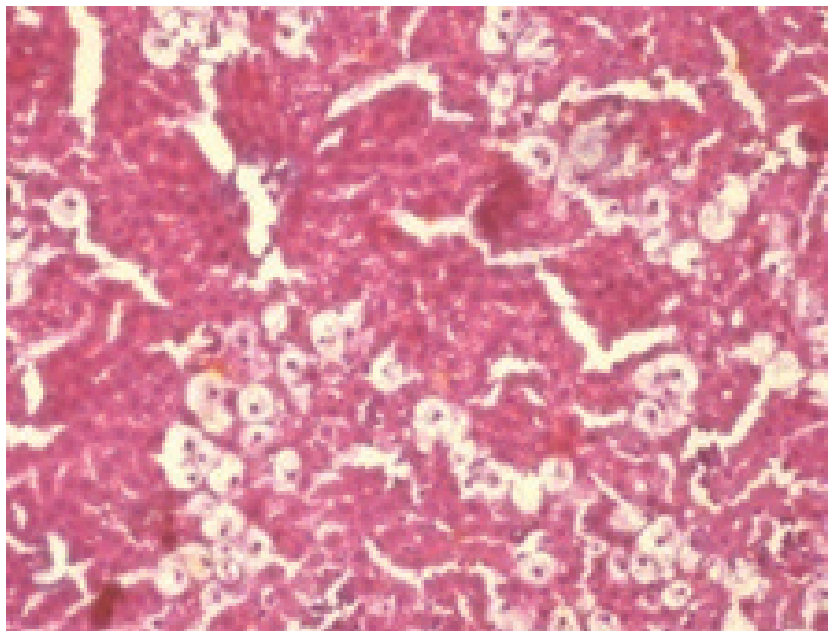

Figure 4: LIAE $(100 \mathrm{mg} / \mathrm{kg})$

$H \& E-100 x$

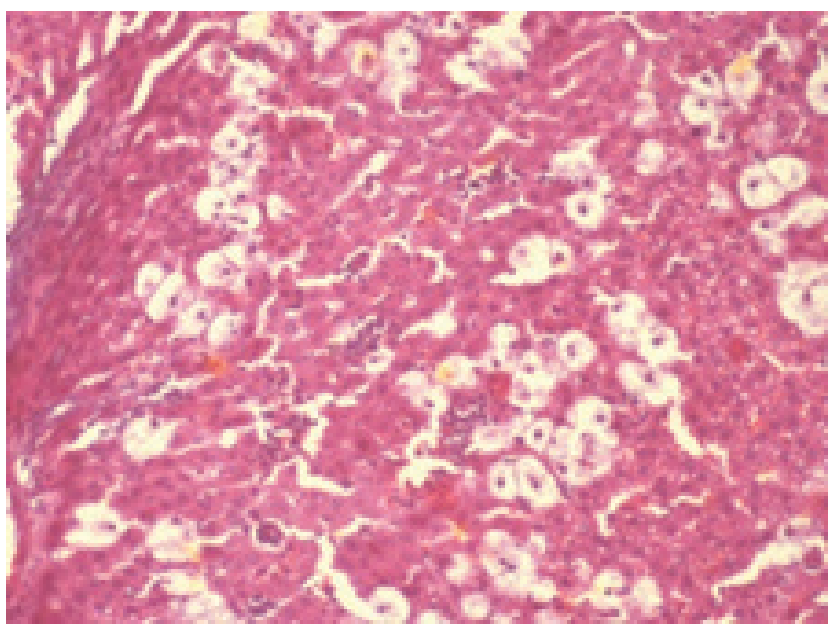

Figure 5: LIAE $(200 \mathrm{mg} / \mathrm{kg})$

$H \& E-100 x$

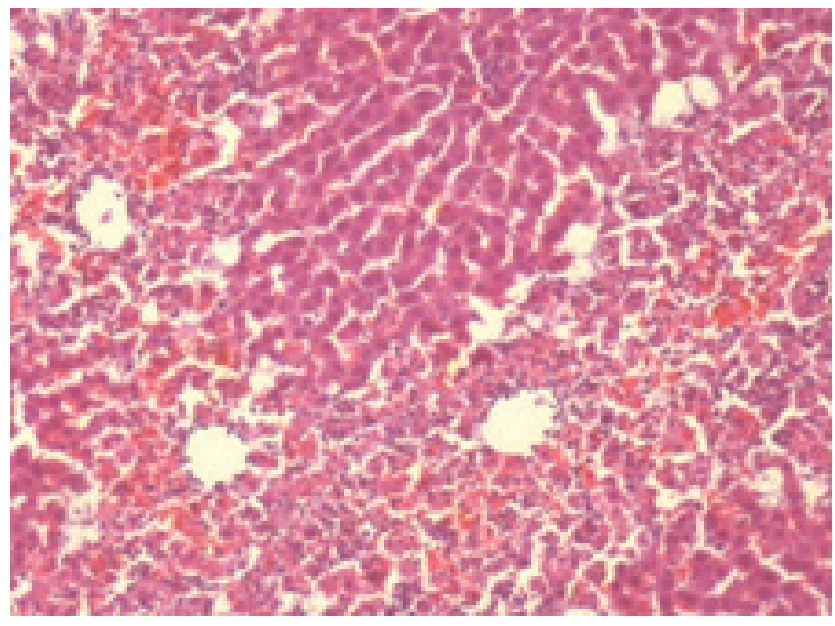

Figure 6: LIAE $(400 \mathrm{mg} / \mathrm{kg})$

$H \& E-100 x$ 


\begin{tabular}{|c|c|c|c|c|c|c|}
\hline Groups & Treatment & $\begin{array}{c}\text { ALT } \\
\text { (IU/L) }\end{array}$ & $\begin{array}{l}\text { AST } \\
\text { (IU/L) }\end{array}$ & $\begin{array}{l}\text { ALP } \\
\text { (IU/L) }\end{array}$ & $\begin{array}{l}\text { TB } \\
\text { (mg/dl) }\end{array}$ & $\begin{array}{c}\text { TP } \\
\text { (g/dl) }\end{array}$ \\
\hline 1 & Normal Control $0.5 \%$ Sodium CMC & $32.64 \pm 2.71$ & $109.7 \pm 9.37$ & $71.86 \pm 9.52$ & $2.718 \pm 0.05$ & $7.407 \pm 0.31$ \\
\hline II & $\mathrm{CCl}_{4}(2 \mathrm{ml} / \mathrm{kg}$ of b.w, i.p. $)$ & $78.77 \pm 2.25^{\mathrm{C}}$ & $168.8 \pm 15^{c}$ & $180.1 \pm 6.44^{c}$ & $13 \pm 0.29 c$ & $3.398 \pm 0.116^{c}$ \\
\hline III & Liv-52, 40mg/kg, p.o & $46.7 \pm 3.63^{\star * *}$ & $114.2 \pm 7.51^{* * *}$ & $87.53 \pm 7.12^{* * *}$ & $4.79 \pm 0.20^{\star * *}$ & $6.57 \pm 0.24^{* \star *}$ \\
\hline IV & LIAE (100mg/kg, b.w, p.o) & $67.52 \pm 4.35$ & $140.1 \pm 6.21$ & $138.2 \pm 12.86^{\star *}$ & $8.845 \pm 0.33^{* * *}$ & $5.292 \pm 0.25^{\star * *}$ \\
\hline V & LIAE (200mg/kg, b.w, p.o) & $59.08 \pm 2.57^{* * *}$ & $131.7 \pm 2.89^{*}$ & $135 \pm 12.85^{* *}$ & $4.975 \pm 0.18^{* * *}$ & $5.765 \pm 0.11^{* * *}$ \\
\hline VI & LIAE (400mg/kg, b.w.p.o) & $57.39 \pm 3.89^{* * *}$ & $128.9 \pm 6.60^{* *}$ & $114.7 \pm 3.69^{* * *}$ & $4.563 \pm 0.11^{\text {***}}$ & $6.057 \pm 0.12^{* * *}$ \\
\hline
\end{tabular}

Values are expressed as Mean \pm SEM. $(n=6) ; * p<0.05, * * p<0.01, * * * p<0.001$ compared to group III

${ }^{a} p<0.05,{ }^{b} p<0.01,{ }^{c} p<0.001$ compared to group I

AST-Aspartate aminotransferase; ALT - Alanine aminotransferase; ALP-Alkaline phosphatase.TB-Total bilirubin, TP-Total protein.

\begin{tabular}{|c|c|c|c|c|c|}
\hline Groups & Treatment & $\begin{array}{c}\text { SOD } \\
\text { (U/mg of protein) }\end{array}$ & $\begin{array}{c}\text { CAT } \\
\text { (U/mg protein) }\end{array}$ & $\begin{array}{c}\text { LPO } \\
\text { ( } \mu \mathrm{M} / \mathrm{mg} \text { protein) }\end{array}$ & $\begin{array}{c}\text { GSH } \\
(\mu \mathrm{M} / \mathrm{mg} \text { Protein })\end{array}$ \\
\hline 1 & Normal Control $0.5 \%$ Sodium CMC & $4.00 \pm 0.32$ & $37.4 \pm 1.17$ & $0.32 \pm 0.02$ & $1.482 \pm 0.07$ \\
\hline II & $\mathrm{CCl}_{4}(2 \mathrm{ml} / \mathrm{kg}$ of b.w, i.p. $)$ & $1.81 \pm 0.48^{c}$ & $21.4 \pm 1.33^{c}$ & $1.97 \pm 0.07^{c}$ & $0.698 \pm 0.03^{c}$ \\
\hline III & Liv-52, 40mg/kg, p.o & $3.04 \pm 0.30$ & $34.7 \pm 1.89^{* * *}$ & $0.53 \pm 0.01^{* * *}$ & $1.355 \pm 0.07^{* * *}$ \\
\hline IV & LIAE (100mg/kg, b.w, p.o) & $1.38 \pm 0.09$ & $26.61 \pm 1.38^{*}$ & $1.11 \pm 0.04^{* * *}$ & $0.86 \pm 0.08$ \\
\hline V & LIAE (200mg/kg, b.w, p.o) & $2.74 \pm 0.57$ & $28.84 \pm 1.18^{* * *}$ & $0.81 \pm 0.05^{* * *}$ & $0.941 \pm 0.06$ \\
\hline VI & LIAE (400mg/kg, b.w,p.o) & $2.91 \pm 0.37$ & $31.24 \pm 0.63^{* * *}$ & $0.625 \pm 0.01^{* * *}$ & $0.916 \pm 0.05$ \\
\hline
\end{tabular}

Values are expressed as Mean \pm SEM. $(n=6) ; * p<0.05, * * p<0.01, * * * p<0.001$ compared to group III

${ }^{\mathrm{a}} \mathrm{p}<0.05,{ }^{\mathrm{b}} \mathrm{p}<0.01,{ }^{\mathrm{c}} \mathrm{p}<0.001$ compared to group I

SOD- Super oxide dismutase, CAT-Catalase, LPO-Lipid peroxidase, GSH-Reduced Glutathione.

\begin{tabular}{|c|c|c|c|c|}
\hline Groups & Treatment & $\begin{array}{c}\text { GPx } \\
(\eta \mathrm{mol} / \mathrm{min})\end{array}$ & $\begin{array}{c}\text { GGT } \\
\text { (nmol/min) }\end{array}$ & $\begin{array}{c}\text { GST } \\
(\eta \mathrm{mol} / \mathrm{min})\end{array}$ \\
\hline I & Normal Control $0.5 \%$ Sodium CMC & $325.2 \pm 2.38$ & $20.33 \pm 0.66$ & $115.7 \pm 1.22$ \\
\hline II & $\mathrm{CCl}_{4}(2 \mathrm{ml} / \mathrm{kg}$ of b.w, i.p. $)$ & $220.5 \pm 2.11^{c}$ & $27.33 \pm 0.66^{c}$ & $95.17 \pm 0.94^{c}$ \\
\hline III & Liv-52, 40 mg/kg, p.o & $281.0 \pm 1.71^{* * *}$ & $22.67 \pm 0.71^{* * *}$ & $107.2 \pm 1.81^{* * *}$ \\
\hline IV & LIAE (100 mg/kg, b.w, p.o) & $223.2 \pm 1.51$ & $27.17 \pm 0.60$ & $94.5 \pm 0.95$ \\
\hline V & LIAE (200 mg/kg, b.w, p.o) & $239.2 \pm 3.32^{* * *}$ & $26.00 \pm 0.57$ & $99 \pm 1.71$ \\
\hline VI & LIAE (400 mg/kg, b.w, p.o) & $257.2 \pm 2.41^{* * *}$ & $25.10 \pm 0.47$ & $105.2 \pm 1.97^{* \star *}$ \\
\hline
\end{tabular}

Values are expressed as Mean \pm SEM. $(n=6) ; * p<0.05, * * p<0.01, * * * p<0.001$ compared to group III

${ }^{\mathrm{a}} \mathrm{p}<0.05,{ }^{\mathrm{b}} \mathrm{p}<0.01,{ }^{\mathrm{c}} \mathrm{p}<0.001$ compared to group I

Glutathione peroxidase-GPx, GGT-Gamma glutamyl Transferase, GST- Glutathione -S-Transferase.

by LIAE in a dose dependent manner. All the aerobic cells contain Superoxide dismutase (SOD) which is one of the important intracellular antioxidant enzymes that possesses antitoxic effects against superoxide anion. ${ }^{33}$ Catalase is a hemoprotein and it protects cells from the accumulation of $\mathrm{H}_{2} \mathrm{O}_{2}$ by dismutating it to form $\mathrm{H}_{2} \mathrm{O}$ and $\mathrm{O}_{2}$ or by using it as an oxidant in which it works as a peroxidase. ${ }^{34}$ GST is another scavenging enzyme which binds to many different lipophilic compounds.
It acts as an enzyme for GSH conjugation reaction. It catalyses the reaction of hydroperoxides with reduced glutathione to form glutathione disulphide (GSSG) and the reduction product of the hydro peroxide. In the current study, treatment with $\mathrm{CCl}_{4}$ produced reduction in the levels of SOD, CAT, GPX, GST and GGT and this is a clear manifestation of excessive formation of free radicals and activation of lipid peroxidation of system resulting in tissue damage. All these antioxidants 
were brought to near normal level $(\mathrm{P}<0.001)$ similar to Liv 52 in the concentration dependent manner.

The site specific oxidative damage of some of the susceptible amino acids of protein is regarded as the major cause of metabolic dysfunction during pathogenesis. ${ }^{35}$ The capacity of liver to synthesize albumin is adversely affected by hepatoxins. The lowered level of total protein recorded in the serum of $\mathrm{CCl}_{4}$ treated rats can be attributed to the features. Attainment of near normalcy in protein content of serum in $\mathrm{CCI}_{4}+\mathrm{LIAE}$ $(400 \mathrm{mg} / \mathrm{kg}$, b.w, p.o) treated rats further confirmed the hepatoprotective effect of Limnanthemum indicum.

It has been suggested that the protective effect of plant extracts against $\mathrm{CCl}_{4}$-induced liver damage may be attributed to the presence of constituents including flavonoids, tannins, triterpenoids and alkaloids. ${ }^{36}$ Flavonoids are known to be antioxidants, free radical scavengers and anti-lipoperoxidants which cause hepato-protection. ${ }^{37-41}$ The hepatoprotective effect of L.indicum against $\mathrm{CCl}_{4}$ induced liver damage could be attributed in part to its antioxidant effect and free radical scavenging activity, ${ }^{42}$ thus, eliminating deleterious effects of toxic metabolites from $\mathrm{CCl}_{4}$ and inducing liver cell regeneration.

In the final phase of the study, histopathological studies were conduceted to further substantiate the protective role of the plant of the present study.

\section{CONCLUSION}

Based on the present study, it can be concluded that ethanolic extract of Limnanthemum indicum (LIAE) exhibited potent hepatoprotective activity in a dose dependent manner. It can be further concluded that flavonoids, a polyphenolic derivative could be the major contributory factor in hepatoprotective activity by strengthening the inbuilt antioxidant system. Further isolation of active principles will be advantageous to produce novel bioactive constituents from these extracts, which may possess more significance in the treatment of liver diseases, and to elucidate its exact mechanism of action.

\section{CONFLICT OF INTEREST}

No conflict of interest are declared.

\section{ABBREVIATIONS USED}

LIAE: Limnanthemum indicum alcoholic extract; $\mathbf{C C l}_{4}$ : Carbon tetrachloride; $\mathbf{C C l}_{3} \bullet$ : Trichloromethyl radical; $\mathrm{CCl}_{3}$ OO•: trichloromethyl peroxy radical; AST: Aspartate aminotransferase 14 ALT-Alanine aminotransferase; ALP: Alkaline phosphatase; TB: Total bilirubin (mg/dL)17 and TP: Total protein; SOD: Super oxide dismutase; CAT: Catalase; LPO: Lipid peroxidase; GSH: Reduced Glutathione; GPx: Glutathione peroxi- dase; GGT: Gamma glutamyl Transferase; GST: Glutathione S-Transferase.

\section{REFERENCES}

1. Singh N, Kamath V, Narasimhamurthy K, Rajini PS. Protective effects of potato peel extract against carbon tetrachloride-induced liver injury in rats. Environ Toxicol Pharmacol. 2008;26(2):141-6. https://doi.org/10.1016/j. etap.2008.05.006 PMid:21791371.

2. Sreelatha S, Padma PR, Umadevi M. Protective effects of Coriandrum sativum on carbon tetrachloride-induced hepatotoxicity in rats. Food Chem Toxicol. 2009;47(4):702-8. https://doi.org/10.1016/j.fct.2008.12.022 PMid:19146910.

3. Srivastava A, Shivanandappa T. Hepatoprotective effect of the root extract of Decalepis hamiltonii against carbon tetrachloride-induced oxidative stress in rats. Food Chem Toxicol. 2010;118(2):411-17. https://doi.org/10.1016/j. foodchem.2009.05.014.

4. Sahreen S, Khan MR, Khan RA. Evaluation of antioxidant activities of various solvent extracts of Carissa opaca fruits. Food Chem. 2010;122(4):1205-11. https://doi.org/10.1016/j.foodchem.2010.03.120.

5. Bohm BA, Nicholls KW, Ornduff R. Flavanoides of meyantheceae; Intra and inter familial relationship. Ameri J bot. 1986;73(2):204-13. https://doi. org/10.2307/2444173.

6. Madhavan V, Shilpi A, Anita M, Yoganarasimhan SN. Anti-convulsant activity of aqueous and alcohol extracts of roots and rhizomes of Nymphoides indica (L.) Kuntze in Swiss albino mice. J Nat Remed. 2009;9(1):68-73.

7. Khare CP, Indian Medicinal Plants-An Illustrated Dictionary. Springer 2007;3(2):374-5.

8. Pandey G, Medicinal plants against liver diseases. Ind Res Jour Pharm. 2011;2(5):115-21.

9. Manosroi J, Boonpisuttinant K, Manosroi W, Mansroi A. Anti-proliferative activities on Hela cancer cell line of Thai medicinal plant recipes selected from Manosroi ii database. J Ethanopharmacol. 2012;142(2):422-37. https:// doi.org/10.1016/j.jep.2012.05.012 PMid:22626926.

10. Tsai MC, Song TY, Shih PH, Yen GC. Antioxidant properties of watersoluble polysaccharides from Antrodia cinnamomea in submerged culture. Food Chemistry. 2007;104(3):1115-22. https://doi.org/10.1016/j. foodchem.2007.01.018.

11. Masters RW. Animal cell culture, Cytotoxicity and viability assays. 2000;ed3:202-3.

12. Francis D, Rita L. Rapid colorimetric assay for cell growth and survival modifications to the tetrazolium dye procedure giving improved sensitivity and reliability. Journal of Immunological Methods. 1986;89(2):271-77. https:// doi.org/10.1016/0022-1759(86)90368-6.

13. The OECD Guideline for Testing of Chemical: 423-Acute Oral Toxicity -Acute Toxic Class Method.OECD, Paris. 2001:1-14.

14. Saravana KA, gandhimathi R, Senthil KKK. Hepatoprotective potential of Cordia subcordata Lam. against $\mathrm{CCl}_{4}$ induced hepatotoxicity in wistar albino rats. J Biomed Sci and Res. 2009;1(1):19-26.

15. Reitman S, Frankel S. A colorimetric method for the determination of serum glutamate oxaloacetate transaminase. American J Clin Pathol. 1957;28:53-6. https://doi.org/10.1093/ajcp/28.1.56.

16. King J. The hydrolases-acid and alkaline phosphatases. In: Practical Clinical Enzymology. Nostrand Company Limited, Londo. 2009:191-208.

17. Malloy HT, Evelyn KA. The determination of bilirubin with the photometric colorimeter. J Biol Chem. 1937;119:481-90.

18. Lowry $\mathrm{OH}$, Rosenbrough $\mathrm{NJ}$, Farr $\mathrm{AL}$ and Randall, RJ. Protein measurement with Folin-Phenol reagent. J Biol Chem. 1951;193(1):265-75. PMid:14907713.

19. Ohkawa H, Onishi N, Yagi K. Assay for lipid peroxides in animal tissue by Thiobarbituric acid reaction. Anal Biochem. 1979;95(2):351-8. https://doi. org/10.1016/0003-2697(79)90738-3.

20. Habig WH, Pabst MJ, Jackoby WB. Glutathione-S transferases: the first enzymatic step in mercapturic acid formation. J Biol Chem. 1974;249(22):7130-9. PMid:4436300.

21. Hochstein $P$, Utley $H$. Hydrogen peroxide detoxication by glutathione peroxidase and catalase in rat liver homogenates. Molecular Pharmaco. 1968;4(6):574-9.

22. Moron MS, Dipieree JW, Mannerwik B. Levels of glutathione, glutathione reductase and glutathione-S-transferase activities in rat lung and 
liver. Biochimica Biophysica Acta. 1979;582(1):67-78. https://doi. org/10.1016/0304-4165(79)90289-7

23. Oynagui $\mathrm{Y}$, Reevaluation of assay methods and establishment of kit for superoxide dismutase activity. Anal Biochem. 1984;142(2):290-6. https://doi. org/10.1016/0003-2697(84)90467-6.

24. Bergmeyer HU, Measurement of catalase activity. Biochemische Zeitschrift. 1955;327:255-96. PMid:13328835.

25. Millard PR. Essential Histopathology, Blackwell Scientific Publications, London. 1990;1-337. PMid:2118602.

26. Gowda S, Desai PB, Hull VV, Math AAK, Vernekar SN, Kulkarni SS. A review on laboratory liver function tests. The Pan African medical journal. 2009;3(17).

27. Lin SC, Yao CJ, Lin CC, Lin YH. Hepatoprotective activity of Taiwan folk medicine: Eclipta prostrate Linn. against various hepatotoxins induced acute hepatotoxicity. Phytother Res. 1996;10(6):483-90. https://doi.org/10.1002/ (SICI)1099-1573(199609)10:6<483::AID-PTR884>3.0.CO;2-2

28. Moss DW, Butterworth PJ. Enzymology and Medicine. Pitman Medical, London. 1974:139. PMid:4154092.

29. Saraswat B, Visen PK, Patnaik GK, Dhawan BN. Anticholestic effect of picroliv, active hepatoprotective principle of Picrorhiza kurrooa, against carbon tetrachloride induced cholestatis. Indian J Exp Biol. 1993;31(4):316-18. PMid:8359830.

30. Vivek Kapur, Pillai KK, Hussain SZ, Balani DK. Hepatoprotective activity of jigrine on liver damage caused by alcohol, carbon tetrachloride and paracetamol in rats. Indian J Pharmacol. 1994;26(1):35-40.

31. Campos R, Garrido A, Valenzuela A, Guerra R. Silybin dihemisuccinate protects against glutathione depletion and lipid peroxidation induced by acetaminophen on rat liver. Planta Med. 1989;55(5):417-19. https://doi. org/10.1055/s-2006-962055 PMid:2813577.

32. Valenzuela A, Lagos C, Schmidt K, Videla K. Silymarin protection against hepatic lipid peroxidation induced by acute ethanol intoxication in the rat. Biochem Pharmacol. 1985;34(12):2209-12. https://doi.org/10.1016/00062952(85)90421-6.

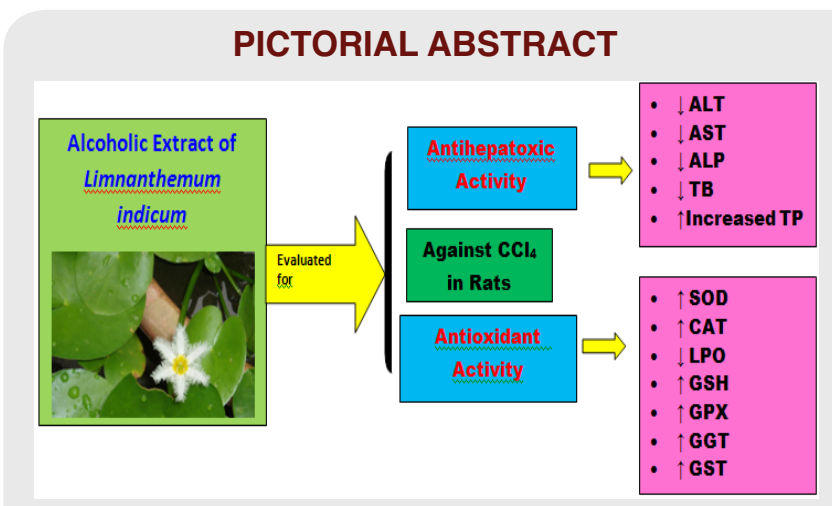

\section{About Authors}

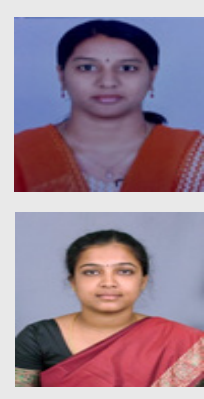

Mrs.Jyothi.Y: She is working as an Associate Professor, in the department of pharmacology at Krupanidhi College of pharmacy, Bangalore-35. Currently she is pursuing her Ph.D programme at Vellore Institute of Technology, vellore, Tamil Nadu. Mrs.Jyothi has research experience in the field of liver toxicity and peptic ulcers.

Professor Dhanaraj Sangeetha: Obtained her Ph.D degree in Environmental Chemistry from Bharathiar University, Tamilnadu. She is an endowed CSIR and Mary Curie Research Fellow by Council of Scientific \& Industrial Research, New Delhi and European Commission, respectively. She is faculty of the postgraduate program in chemistry, VIT University, Vellore since 2008. Dr. Sangeetha has research experience in the area of Analytical Chemistry comprising Pharmaceutical analysis, Phytochemical analysis, Formulation of Nanomaterials for Environmental and Drug Delivery applications

Cite this article: Yachamaneni J, Dhanraj S. Anti-Hepatotoxic and Antioxidant Activity of Limnanthemum indicum Against Carbon Tetrachloride Induced Liver Toxicity in Rats. Indian Journal of Pharmaceutical Education and Research. 2017;51(2):321-8. 